\title{
Dairy cows grazing an alpine pasture: effect of pattern of supplement allocation on herbage intake, body condition, milk yield and coagulation properties
}

\author{
Stefano Bovolenta ${ }^{\mathrm{a} *}$, Walter VenturA ${ }^{\mathrm{b}}$, Franco MALOSSINI ${ }^{\mathrm{a}}$ \\ ${ }^{a}$ Dipartimento di Scienze della Produzione Animale, Università di Udine, via S. Mauro 2, \\ 33010 Pagnacco (UD), Italy \\ ${ }^{b}$ Istituto Agrario, via E. Mach 2, 38010 S. Michele all'Adige (TN), Italy
}

(Received 4 January 2001; accepted 14 March 2002)

\begin{abstract}
The effect of two patterns of concentrate allocation were studied on twenty-eight Italian Brown cows (initial milk yield, $19.4 \mathrm{~kg} \cdot \mathrm{d}^{-1}$ ) grazing an alpine pasture. One group was supplemented at a flat rate, based on the initial milk production (Flat Supplement, FS), while the second was supplemented at a declining rate, according to the decline of lactation (Declining Supplement, DS). During an 8 -week period in July and August, the cows were moved onto 8 successive sectors, ensuring a daily herbage allowance of $20 \mathrm{~kg}$ of dry matter per cow. The crude protein content of the herbage decreased from $19.5 \%$ at the beginning to $12.4 \%$ at the end, while the fibre fractions showed an opposite trend. The DS group showed a slightly higher, not significant, herbage intake (10.9 vs. $\left.10.6 \mathrm{~kg} \mathrm{OM} \cdot \mathrm{d}^{-1}\right)$. BCS changes were in no case different from 0 . The milk yield was positively affected by the FS $\left(17.0 \mathrm{~kg} \cdot \mathrm{d}^{-1} \mathrm{vs} .15 .2 \mathrm{~kg} \cdot \mathrm{d}^{-1}\right)$; no difference was observed in milk composition. Coagulation properties were satisfactory without any appreciable effect of the two treatments.
\end{abstract}

dairy cow / pasture / supplementation / herbage intake / milk production

Résumé - Vaches laitières au pâturage alpin : effet des modalités de la distribution de l'aliment concentré sur la quantité d'herbe ingérée, l'état corporel, la production de lait et son aptitude à la coagulation. Vingt-huit vaches laitières de race Brune italienne (production moyenne initiale de lait : $19,4 \mathrm{~kg} \cdot \mathrm{j}^{-1}$ ), conduites sur un pâturage alpin, ont été réparties en 2 lots qui différaient par les modalités d'allocation du concentré. Dans le premier lot, les vaches recevaient une quantité constante de concentré, calculée d'après la production et la composition du lait pendant une période préliminaire d'une semaine (lot FS). Dans le second, elles recevaient une quantité de concentré décroissante, sur la base d'une production laitière persistante de $97 \%$ par semaine (lot DS). Pendant l'essai, d'une durée de huit semaines (juillet-août), les animaux ont successivement pâturé 8 secteurs

*Correspondence and reprints

Tel.: 39 (0)432 650110; fax: 39 (0)432 660614; e-mail: stefano.bovolenta@dspa.uniud.it 
dans lesquels la disponibilité en herbe était d'environ $20 \mathrm{~kg}$ de matière sèche par jour. La teneur en matières azotées totales de l'herbe a diminué de 19,5\% (de la matière sèche) à $12,4 \%$ pendant l'essai, tandis que celle en fractions fibreuses a présenté une évolution inverse. Le lot DS a été caractérisé par une ingestion plus faible de concentré (3,5 kg vs. $4,5 \mathrm{~kg}$ de matière organique par jour) et légèrement plus élevée d'herbe $\left(+0,3 \mathrm{~kg} \mathrm{MO} \cdot \mathrm{j}^{-1}\right.$; différence non significative $)$. Les variations de la note d'état corporel n'ont pas été significativement différentes de 0 . La production de lait a été augmentée avec le traitement FS (17,0 vs. $\left.15,2 \mathrm{~kg} \cdot \mathrm{j}^{-1}\right)$. La composition du lait n'a pas présenté de différences significatives. Les propriétés de coagulation du lait ont été satisfaisantes et n'ont pas été affectées par les traitements.

vache laitière / pâturage / supplémentation / ingestion d'herbe / production laitière

\section{INTRODUCTION}

The exploitation of mountain pastures by grazing with dairy cows offers advantages for the economy of many rural areas, the health of the animals and the protection of the environment, but it also poses feeding problems which are not easy to solve. The pastures, especially those located at the highest altitudes, may not be capable of meeting the nutritional requirements of the animals, increased by the movement involved and by the low temperatures. Under these conditions, there is often a fall in milk production - also related to the number of days in milk and the genetic merit of the cows $[21,31]$ - normally accompanied by a failure to recover body condition $[1,12,22$, 31].

In order to offset these effects, it is generally necessary to supplement with concentrates, whose benefit in terms of increased level of nutrition is conditioned by the possible reduction in the amount of herbage consumed. Much research has been conducted on dairy cows at pasture to establish the effect of the level and quality of the concentrates offered. Less research has been done on the pattern of supplement allocation [18].

The objective of this experiment, carried out on a high altitude alpine pasture, was to evaluate the effect of a flat or declining rate of concentrate supplementation on herbage intake, body condition, milk yield and qual- ity, including coagulation properties since the milk produced in these environments is always used for cheese making.

\section{MATERIALS AND METHODS}

\subsection{Pasture and grazing management}

The experiment was carried out for 8 weeks, from July 2 to August 27 on a high mountain pasture in the eastern Alps region (Malga Juribello, Province of Trento, Italy), within the "Paneveggio - Pale di S. Martino" Natural Park. The 20 ha experimental area, divided by electric fences into 8 sectors, was located at an altitude of 1800-2000 m. The pasture was mainly a Poion alpinae with the presence of high feeding value species such as Poa alpina, Phleum alpinum, Trifolium pratense, Tr. repens; the weed species were mainly Deschampsia cespitosa and Rumex alpinus. The only sort of fertiliser applied was manure.

During the experimental period the pasture was utilised by weekly moving the animals into 8 sectors, starting with those located at the lowest altitude. In the pre-experimental period, the cows grazed a contiguous sector with a similar botanical composition. The sector area was calculated so as to ensure a mean daily herbage allowance per cow of $20 \mathrm{~kg}$ dry matter (DM). 


\subsection{Animals, treatments and experimental design}

Twenty-eight lactating Italian Brown cows (potential $7600 \mathrm{~kg}$ per lactation \pm 12 ) were assigned to two groups balanced for daily milk yield (average $19.4 \mathrm{~kg} \pm 2.1$ ), days in milk (206 d \pm 28$)$, parities (2.6 \pm 1.5$)$, body condition score (BCS, $3.24 \pm 0.34$ ), and live weight (LW, $563 \mathrm{~kg} \pm 32$ ). The groups were different for the pattern of supplement allocation: the first was supplemented at a flat rate, based on the milk production and composition during a one week preliminary period (group Flat Supplement, FS); the second was supplemented at a declining rate, on the basis of a lactation persistency of 0.97 per week (group Declining Supplement, DS). All cows grazed together during the experiment.

The concentrate was offered at a rate of $1 \mathrm{~kg}$ as fed per $2.1 \mathrm{~kg}$ of energy corrected milk (ECM) [6] exceeding $10 \mathrm{~kg}$. The composition of the compound feed was as follows: maize and barley $40 \%$, maize germ $20 \%$, wheat bran $16.5 \%$, sunflower oil meal $6 \%$, soybean flakes $5 \%$, dry sugar beet pulp $5 \%$, molasses $2 \%$, mineral-vitamin supplement $5.5 \%$ (yeast $1 \%$, calcium carbonate $1.2 \%$, calcium phosphate $1.0 \%$, salt $0.8 \%$, bentonite $1.0 \%$, vitamins and microelements $0.5 \%$ ); crude protein (CP) $15.1 \% \mathrm{DM}$, crude fibre (CF) 8.4\% DM, 1.03 UFL (milk feed units) $\mathrm{kg}^{-1} \mathrm{DM}$ [9]. For both groups the initial amount of concentrate was $5.5 \mathrm{~kg} \cdot \mathrm{d}^{-1}$ as fed (4.5 $\mathrm{kg} \mathrm{OM})$. In the first 4 weeks, $1 \mathrm{~kg}$ of compound feed was replaced by an equal amount of dried sugar beet pulp (CP 8.6\% DM, CF 20.3\% DM, UFL $1.00 \mathrm{~kg}^{-1} \mathrm{DM}$ ) in order to balance the high protein and low fibre content of the pasture. Supplement was offered twice daily during milking, with any possible refusal being recorded. The animals were kept continuously on the pasture, except during the two daily milkings (about $4 \mathrm{~h}$ per day).

\subsection{Measurements and chemical analyses}

The weather conditions were recorded using an automatic weather station, which constantly recorded the temperature and precipitation.

The herbage mass offered in each sector was assessed by cutting five $1.5 \mathrm{~m}^{2}$ strips at a height of 4-5 cm above ground level. Subsamples of herbage were dried in a forced draught oven at $65^{\circ} \mathrm{C}$ for the determination of the DM content.

Samples of the grazed herbage were hand-plucked from within five $1 \mathrm{~m}^{2}$ cages located in each sector so as to simulate the feeding selection of the animals. The dried samples were bulked by sector ( 5 samples into 1 per sector) and analysed for $\mathrm{CP}, \mathrm{CF}$, ash [2] and fibre fractions [10]; the organic matter digestibility (OMD) was determined in vitro with an enzymatic method [4]. The nutritive value of the herbage was determined according to INRA [15].

The estimate of herbage intake was carried out by n-alkane method [20]. In two periods of 10 days, from July 5 to 14 and from August 10 to 19, the animals were dosed every morning with a gelatine capsule containing $600 \mathrm{mg}$ of $\mathrm{C}_{32}$ (dotriacontane) on paper. In the last 3 days of each period, when the animals were in the middle of the grazing period respectively of sectors 2 and 7 , grab samples of the faeces were taken after each milking (at about 07.00 and $19.00 \mathrm{~h}$ ). The individual faecal samples, dried and bulked per period (6 samples into 1 , per period and per cow), and the samples of grazed herbage of sectors 2 and 7 were analysed for their n-alkane concentration. The estimate of herbage intake was based on the concentration of a pair of alkanes, namely $\mathrm{C}_{32}$ and $\mathrm{C}_{31}$ (entriacontane), the odd-chain alkane being present in the grazed herbage at the greatest level. 
Milk yield was recorded and milk samples were collected twice daily for 2 consecutive days every 2 weeks. Individual samples were analysed for protein, fat and lactose with an infrared Milk-o-scan apparatus and for somatic cell count with a Foss-o-matic apparatus. On the morning milk samples, the titratable acidity $\left({ }^{\circ} \mathrm{SH} \cdot 50 \mathrm{ml}^{-1}\right)$ was measured and the coagulation properties - rennet clotting time (r), time for aggregation $\left(\mathrm{k}_{20}\right)$ and gel firmness $\left(\mathrm{a}_{30}\right)$ - were determined with a Foss Electric Formagraph [25].

LW was recorded at the beginning and at the end of the experiment. At the same time, the BCS was determined by 2 independent evaluators according to a 5-point scale [8].

\subsection{Statistical analysis}

The effect of the two patterns of supplement allocation on milk yield $(a)$, milk composition $(b)$ and herbage intake $(c)$ were studied by analysis of variance, using as covariates:

- the production of the preliminary period and the initial metabolic LW for $a$;

- the values of the preliminary period for $b$;
- the mean metabolic LW for $c$.

The traits linked to cheese making were analysed without covariates.

The significance of the variations of BCS was evaluated within each group as a difference from 0 by the " $\mathrm{t}$ " test for paired comparisons.

\section{RESULTS}

\subsection{Meteorological recordings}

The alpine climate is characterised by long, cold winters and cool, wet summers. In the experimental period, July was colder and noticeably wetter than August (mean daily temperature: 10.6 vs. $12.2^{\circ} \mathrm{C}$; total precipitation: 147 vs. $119 \mathrm{~mm}$ ). Over the entire period, the mean temperature was $11.4{ }^{\circ} \mathrm{C}$, with an absolute minimum of $2.8^{\circ} \mathrm{C}$ recorded at the beginning of July and a maximum of $19.8^{\circ} \mathrm{C}$ in the middle of $\mathrm{Au}$ gust.

\subsection{Pasture}

Table I shows the main traits of the pasture. The herbage mass averaged 1.6 ton

Table I. Herbage mass offered and chemical composition and digestibility of grazed herbage.

\begin{tabular}{lrrrrrrrr}
\hline & \multicolumn{7}{c}{ Grazed sectors (weeks) } \\
\cline { 2 - 8 } & \multicolumn{1}{c}{1} & \multicolumn{1}{c}{2} & \multicolumn{1}{c}{3} & \multicolumn{1}{c}{4} & \multicolumn{1}{c}{5} & \multicolumn{1}{c}{6} & \multicolumn{1}{c}{7} & \multicolumn{1}{c}{8} \\
\hline Herbage mass (t DM·ha ${ }^{-1}$ ) & 1.1 & 1.3 & 1.5 & 1.6 & 1.7 & 1.9 & 2.0 & 2.1 \\
Grazed herbage: & & & & & & & & \\
$\quad$ Crude protein (\% DM) & 19.5 & 18.2 & 17.2 & 16.6 & 15.2 & 15.6 & 14.3 & 12.4 \\
Crude fibre (\% DM) & 19.4 & 20.6 & 21.6 & 22.2 & 23.5 & 24.3 & 25.2 & 26.2 \\
Ash (\% DM) & 6.9 & 7.3 & 7.8 & 7.3 & 6.4 & 6.6 & 6.4 & 7.2 \\
NDF (\% DM) & 43.4 & 46.0 & 47.4 & 51.9 & 56.8 & 58.2 & 59.3 & 60.0 \\
ADF $^{2} \%$ DM) & 21.6 & 24.7 & 29.7 & 32.6 & 33.2 & 33.3 & 32.8 & 32.4 \\
ADL $^{3}(\% \mathrm{DM})$ & 4.5 & 6.9 & 6.9 & 7.0 & 7.2 & 7.1 & 7.6 & 7.9 \\
OMD $^{4}(\%)$ & 77.4 & 71.9 & 68.7 & 63.3 & 60.7 & 60.9 & 57.8 & 56.6 \\
UFL $^{5} \mathrm{~kg}^{-1} \mathrm{DM}$ & 0.98 & 0.89 & 0.84 & 0.76 & 0.73 & 0.73 & 0.69 & 0.66 \\
\hline
\end{tabular}

\footnotetext{
${ }^{1}$ Neutral detergent fibre.

${ }^{2}$ Acid detergent fibre.

${ }^{3}$ Acid detergent lignin.

${ }^{4}$ Organic matter digestibility.

${ }^{5}$ Milk feed units.
} 
$\mathrm{DM} \cdot \mathrm{ha}^{-1}$, and increased progressively from 1.1 ton $\mathrm{DM} \cdot \mathrm{ha}^{-1}$ in sector 1 to 2.1 ton DM.ha ${ }^{-1}$ in sector 8 , grazed first and last respectively. The CP content of grazed herbage was very high at the beginning (19.5\%) and declined progressively to $12.4 \%$. The fibre fractions showed an opposite trend with a continuous increase during the experimental period. Consequently, the OMD diminished from $77.4 \%$ in the first sector to $56.6 \%$ in the last one and the feed value from 0.98 UFL to 0.66 UFL.

\subsection{Feed intake and animal performance}

The concentrate administered was almost entirely consumed by both groups. The DS group ate, on average, $1 \mathrm{~kg}$ of $\mathrm{OM} \cdot \mathrm{d}^{-1}$ less than the FS group; at the end of the experimental period, this difference was $2 \mathrm{~kg}$ of OM$\cdot \mathrm{d}^{-1}$ (Tab. II). The herbage intake was slightly higher $\left(+0.3 \mathrm{~kg} \mathrm{OM} \cdot \mathrm{d}^{-1}\right.$, not significant) in the DS group. The average intake of the two groups was $10.7 \mathrm{~kg}$ $\mathrm{OM} \cdot \mathrm{d}^{-1}$, with a mean decrease of $1.6 \mathrm{~kg}$ from the first control (July) to the second (August).

BCS changes were slightly negative in the DS group, but not significantly different from 0 .

The production of milk and ECM was higher in the FS group than the DS $(+12.7 \%$ and $+11.8 \%$ respectively, $P<0.001)$ and the same trend was observed for the daily production of protein $(+13.7 \%, P<0.05)$, fat $(+5.7 \%, P<0.05)$ and lactose $(+11.0 \%, P<0.01)$. No significant differences were observed in milk composition.

The coagulation properties of the milk (Tab. III) were slightly better in the DS group but with no significant difference. In the same group, the number of somatic cells was a little higher (n.s.).

\section{DISCUSSION}

The vegetative cycle in the high mountains is considerably shorter than that of the plains, with a consequent rapid worsening

Table II. Feed intake, $\mathrm{BCS}^{1}$ changes, milk yield and composition.

\begin{tabular}{|c|c|c|c|c|}
\hline & \multicolumn{2}{|c|}{ Supplement allocation } & \multirow[t]{2}{*}{ Significance } & \multirow[t]{2}{*}{$\mathrm{RSD}^{2}$} \\
\hline & $\begin{array}{l}\text { Flat } \\
\text { (FS) }\end{array}$ & $\begin{array}{l}\text { Declining } \\
\text { (DS) }\end{array}$ & & \\
\hline $\begin{array}{l}\text { Supplement intake }\left(\mathrm{kg} \mathrm{OM} \cdot \mathrm{d}^{-1}\right) \\
\text { (start-end) }\end{array}$ & $\begin{array}{c}4.5 \\
(4.5-4.5)\end{array}$ & $\begin{array}{c}3.5 \\
(4.5-2.5)\end{array}$ & $\begin{array}{l}- \\
-\end{array}$ & $\begin{array}{l}- \\
-\end{array}$ \\
\hline $\begin{array}{l}\text { Herbage intake }\left(\mathrm{kg} \mathrm{OM} \cdot \mathrm{d}^{-1}\right) \\
\quad \text { (July-August) }\end{array}$ & $\begin{array}{c}10.6 \\
(11.3-9.8)\end{array}$ & $\begin{array}{c}10.9 \\
(11.7-10.0)\end{array}$ & ns & $\begin{array}{c}1.31 \\
-\end{array}$ \\
\hline $\mathrm{BCS}^{1}$ change & $0.03 \mathrm{~ns}^{0}$ & $-0.16 \mathrm{~ns}^{0}$ & - & - \\
\hline $\operatorname{Milk}\left(\mathrm{kg} \cdot \mathrm{d}^{-1}\right)$ & 16.9 & 15.0 & $* * *$ & 0.96 \\
\hline $\operatorname{ECM}^{3}\left(\mathrm{~kg} \cdot \mathrm{d}^{-1}\right)$ & 17.0 & 15.2 & $* * *$ & 0.83 \\
\hline Protein $\left(g \cdot \mathrm{kg}^{-1}\right)$ & 33.4 & 33.6 & ns & 1.24 \\
\hline Fat $\left(\mathrm{g} \cdot \mathrm{kg}^{-1}\right)$ & 40.3 & 41.6 & ns & 2.95 \\
\hline Lactose $\left(\mathrm{g} \cdot \mathrm{kg}^{-1}\right)$ & 49.5 & 49.7 & ns & 0.99 \\
\hline Protein $\left(\mathrm{g} \cdot \mathrm{d}^{-1}\right)$ & 563 & 495 & $*$ & 39 \\
\hline Fat $\left(g \cdot d^{-1}\right)$ & 662 & 626 & $*$ & 40 \\
\hline Lactose $\left(g \cdot d^{-1}\right)$ & 830 & 748 & $* *$ & 43 \\
\hline
\end{tabular}

$* P<0.05 ; * * P<0.01 ; * * * P<0.001$; ns: $P>0.05 ;$ ns $^{0}$ : not significantly different from 0 .

${ }^{1}$ Body condition score.

${ }^{2}$ Residual standard deviation.

${ }^{3}$ Energy corrected milk $=750 \mathrm{kcal} \cdot \mathrm{kg}^{-1}[6]$. 
Table III. Coagulation properties, titratable acidity and somatic cell counts.

\begin{tabular}{|c|c|c|c|c|}
\hline & \multicolumn{2}{|c|}{ Supplement allocation } & \multirow[t]{2}{*}{ Significance } & \multirow[t]{2}{*}{$\mathrm{RSD}^{1}$} \\
\hline & $\begin{array}{l}\text { Flat } \\
\text { (FS) }\end{array}$ & $\begin{array}{l}\text { Declining } \\
\text { (DS) }\end{array}$ & & \\
\hline Rennet clotting time (r, min) & $14^{\prime} 54^{\prime \prime}$ & $13^{\prime} 42^{\prime \prime}$ & ns & $3^{\prime} 54 \prime$ \\
\hline Time for aggregation $\left(\mathrm{k}_{20}, \mathrm{~min}\right)$ & $7 ' 12 ”$ & $6 ’ 42 ”$ & ns & $2 ’ 26 ”$ \\
\hline Gel firmness $\left(\mathrm{a}_{30}, \mathrm{~mm}\right)$ & 25.5 & 28.3 & ns & 7.83 \\
\hline Titratable acidity $\left({ }^{\circ} \mathrm{SH}\right)$ & 3.1 & 3.3 & ns & 0.25 \\
\hline Somatic cell count $\left(\times 10^{3} \mathrm{ml}^{-1}\right)$ & 301 & 347 & ns & 251 \\
\hline
\end{tabular}

ns: $P>0.05$

${ }^{1}$ Residual standard deviation.

of the chemical and nutritional values in the late summer. Over the 8-week period, the content of CP and NDF in the grazed herbage changed by $-36 \%$ and $+38 \%$ respectively which was in line with this general trend. Given the grazing technique adopted - the animals were moved successively onto new sectors with a high stocking density - and as a consequence of a high utilisation rate of the pasture, the composition of the consumed herbage reasonably reflected the evolution of the herbage mass offered. In different grazing conditions, when the herbage availability per cow is higher, or when continuous stocking is practised, the possibility of selection by the animals increases so that the diet is less variable [7] and less related to the herbage mass offered [30].

The herbage intake was on the average rather low because of the reduced daily availability and of the low herbage quantity per surface unit, a condition that lowers even more the intake ability. According to Hodgson [14], intake decreases when the herbage mass falls below a value between 1.2 and $2.8 \mathrm{t} \mathrm{OM} \cdot \mathrm{ha}^{-1}$, while Peyraud et al. [28] observed a noticeable fall below $2.5 \mathrm{t}$ $\mathrm{OM} \cdot \mathrm{ha}^{-1}$. In August, although the herbage mass offered was something higher, the herbage intake fell further, very likely owing to a worsening of the chemical and nutritional traits.

In the FS group, the higher supplement intake corresponded to a lower herbage in- take. As a mean for the whole period, $1 \mathrm{~kg}$ $\mathrm{OM} \cdot \mathrm{d}^{-1}$ more supplement led to a reduction in herbage intake of $0.3 \mathrm{~kg} \mathrm{OM} \cdot \mathrm{d}^{-1}$, equal to a substitution rate (SR) of 0.3 . The SR, however interesting it may be from a physiological and economical point of view, is very variable in different situations, since it is affected by many factors, such as the herbage availability and its quality, the type of concentrate and the production level. In particular, the SR tends to be lower when herbage availability is low $[11,27]$.

None of the groups were able to recover body reserves, a recovery, which normally occurs during late lactation. However, in potentially high producing dairy cows the partitioning of the nutrients tends more towards the production of milk rather than towards tissue gain. As a consequence, the recovery of live-weight can only be obtained with a high energy intake [3].

The plane of nutrition of the FS group led to a little increase in concentrate intake and a considerable increase in milk production: in terms of ECM, the increase was $1.80 \mathrm{~kg} \cdot \mathrm{d}^{-1}$. In comparison with the DS group, the marginal response was thus $1.46 \mathrm{~kg} \mathrm{ECM} \cdot \mathrm{kg}^{-1}$ concentrate as fed $(1 \mathrm{~kg}$ $\mathrm{OM}=1.23 \mathrm{~kg}$ as fed $\cdot \mathrm{d}^{-1}$ ), a very high value compared with the $0.3-0.6 \mathrm{~kg}$ milk $\cdot \mathrm{kg}^{-1} \mathrm{ex}-$ tra concentrate reported by various reviews $[16,17]$ and in more recent papers $[5,12,13]$. According to Mayne and Peyraud [26], the production response to the supplementation with concentrates is strongly influenced, as 
for SR, by herbage availability. A low herbage availability could thus partly justify the high marginal response to the supplementation with concentrates. Nevertheless other reasons can explain the better results for the FS group, in particular the flat allocation even with falling milk production probably compensated for the progressive worsening of the nutritional quality of the pasture. This aspect is undoubtedly of considerable relevance for animals grazing alpine pastures in the summer period, when the decline in quality of the pasture is very rapid.

In order to verify the correspondence of the experimental data, an energy balance between the values of input (supplement + herbage) and output (maintenance + ECM production) was calculated. The balance response was positive of 1.72 UFL for the FS group and of 1.56 UFL for the DS group. Because there was no appreciable variation of the body condition, the gap may be justified by an overestimation of herbage intake $(+24 \%$ for the FS group and $+20 \%$ for the DS group) or by a higher energetic expense for grazing in high and sloping pastures (+ $36 \%$ with respect to maintenance for the FS group and $+32 \%$ for the DS group) or by both factors. Since the second one was certainly present, although not easily quantifiable, the estimated error of herbage intake would be rather low. In the hypothesis of an increase of the maintenance of $25 \%$, a value recorded by Zemp in cows grazing on mountains [31], the overestimation of herbage intake would only have been $0.6 \mathrm{~kg}$ $\mathrm{OM}$, equal to $+6 \%$, for the FS group and $0.4 \mathrm{~kg} \mathrm{OM}$, equal to $+4 \%$, for the DS group. With this arrangement, the energy balance may have been considered equal to zero, thus justifying the non-recovery of body reserves.

The pattern of supplement allocation had no effect on milk composition. The consequent difference between the levels of supplementation was presumably not enough to modify in an appreciable way the herbage/ concentrate ratio. The combined effect of the quantity and composition of milk for the FS group led to a higher fat and protein yield, an important aspect when the milk production, as is usual in the alpine environment, is utilised for cheese making.

The lack of an appreciable effect of the dietary treatments on milk composition extended to its coagulation properties. In any case, the coagulation properties can be retained as satisfactory given the late stage of lactation [19], and in agreement with the mean values reported for the Italian Brown cows $[23,24]$.

The number of somatic cells was rather high, but not unusual for cows grazing alpine pastures and at a late stage of lactation. These values are, however, compatible with good cheese making, which is negatively affected by SCC values higher than 400000 [29].

\section{CONCLUSIONS}

This experiment showed that in the condition of an alpine pasture grazed in the summer by dairy cows, the best results as far as milk yield is concerned were obtained by a constant level of concentrates. This plane of nutrition involved a slightly higher concentrate supply, with a little lower herbage intake, but mainly allowed to balance the rapid and progressive worsening of herbage feed value. On alpine pastures, where automatic equipment for distributing supplements is practically absent, this pattern of concentrate allocation is advisable also for its greater simplicity of management. The milk composition, its coagulation properties and the BCS were not affected by the pattern of concentrate allocation.

\section{ACKNOWLEDGEMENTS}

This experiment received financial support from the Consiglio Nazionale delle Ricerche 
(CNR). The authors wish to thank dott. C. Valorz (Federazione Provinciale Allevatori, Trento) for the availability of the Juribello Malga.

\section{REFERENCES}

[1] Andrighetto I., Ramanzin M., Sfruttamento del cotico erboso e produzioni di latte di vacche al pascolo, Zootech. Nutr. Anim. 13 (1987) 119-127.

[2] AOAC, Official methods of analysis, 15th edition, AOAC, Arlington, Virginia, USA, 1990.

[3] Agnew R.E., Yan T., Gordon F.J., Nutrition of the high genetic merit dairy cows - energy metabolism studies, in: Garnsworthy P.C., Wiseman J. (Eds.), Recent advances in animal nutrition, Nottingham University Press, Nottingham, UK, 1998, pp. 181-208.

[4] Aufrère J., Étude de la prévision de la digestibilité des fourrages par une méthode enzymatique, Ann. Zootech. 31 (1982) 111-130.

[5] Berzaghi P., Herbein J.H., Polan C.E., Intake, site and extent of nutrient digestion of lactating cows grazing pasture, J. Dairy Sci. 79 (1996) 1581-1589.

[6] Bickel H., Fat-corrected milk (FCM), an inaccurate and confusing term, Livest. Prod. Sci. 18 (1988) 311-313.

[7] Bovolenta S., Ventura W., Piasentier E., Malossini F., Supplementation of dairy cows grazing an alpine pasture: effect of concentrate level on milk production, body condition and rennet coagulation properties, Ann. Zootech. 47 (1998) 169-178.

[8] Edmonson A.J., Lean I.J., Weaver L.D., Farver T., Webster G., A body condition scoring for Holstein dairy cows, J. Dairy Sci. 72 (1989) 68-78.

[9] Giger-Reverdin S., Aufrère J., Sauvant D., Demarquilly C., Vermorel M., Pochet S., Prévision de la valeur énergétique des aliments composés pour les ruminants, INRA Prod. Anim. 3 (1990) 181-188.

[10] Goering H.K., Van Soest P.J., Forage fiber analyses (apparatus, reagent, procedures and some applications), US Department of Agriculture, Agriculture Handbook No. 379, 1970.

[11] Grainger C., Mathews G.L., Positive relation between substitution rate and pasture allowance for cows receiving concentrates, Aust. J. Exp. Agric. 29 (1989) 355-365.

[12] Hauwuy A., Bornard A., Coulon J.B., Haltel L., Performances des vaches laitières en alpage: effet du niveau de la complémentation en aliment concentré, INRA Prod. Anim. 6 (1993) 289-295.
[13] Hoden A., Peyraud J.L., Muller A., Delaby L., Faverdin P., Simplified rotational grazing management of dairy cows: effects of rates of stocking and concentrate, J. Agric. Sci. Camb. 116 (1991) 417-428.

[14] Hodgson J., Ingestive behaviour, in: Leaver J.D. (Ed.), Herbage intake handbook, Br. Grassl. Soc., Oxford, UK, 1982, pp. 113-138.

[15] INRA, Alimentation des bovins, ovins et caprins, INRA Paris, 1988, $471 \mathrm{p}$.

[16] Journet M., Demarquilly C., Feeding strategy for the high yielding cow, in: Broster W.H., Swan H. (Eds.), Grazing, European Association of Animal Production Publ. No. 25, Granada Publ., New York, USA, 1979.

[17] Leaver J.D., Effects of supplements on herbage intake and performance, in: Frame J. (Ed.), Grazing, European Association of Animal Production, Occasional Symposium No. 19, 7988, 1986.

[18] Leaver J.D., Level and pattern of concentrate allocation to dairy cows, in: Garnsworthy P.C. (Ed.), Nutrition and lactation in the dairy cows, Butterworths, UK, 1988, pp. 315-326.

[19] Lucey J., Cheesemaking from grass based seasonal milk and problems associated with late-lactation milk, J. Soc. Dairy Tech. 49 (1996) 59-64.

[20] Mayes R.W., Lamb C.S., Colgrove P.M., The use of dosed and herbage n-alkanes as markers for the determination of herbage intake, J. Agric. Sci. Camb. 107 (1986) 161-170.

[21] Malossini F., Bovolenta S., Pradi P.P., Piras C., Effetto dell'alpeggio sulla produzione di latte di bovine di razza Bruna, Zootech. Nutr. Anim. 18 (1992) 259-265.

[22] Malossini F., Bovolenta S., Piras C., Ventura W., Effect of concentrate supplementation on herbage intake and milk yield of dairy cows grazing an alpine pasture, Livest. Prod. Sci. 43 (1995) 119-128.

[23] Malossini F., Bovolenta S., Piras C., Dalla Rosa M., Ventura W., Effect of diet and breed on milk composition and rennet coagulation properties, Ann. Zootech. 45 (1996) 29-40.

[24] Mariani P., Pecorari M., Fossa E., Le caratteristiche di coagulazione del latte in rapporto allo stadio della lattazione e ai livelli di produzione, Scienza e Tecnica Lattiero Casearia 33 (1982) 409-425.

[25] McMahon D.J., Brown R.J., Evaluation of Formagraph for comparing rennet solutions, J. Dairy Sci. 65 (1982) 1639-1642.

[26] Mayne C.S., Peyraud J.L., Recent advances in grassland utilisation under grazing and conservation, in: Parente G., Frame J., Orsi S. (Eds.), Grassland and land use systems, British Grassland Society, Reading, UK, 1996, pp. 347-360.

[27] Meijs J.A.C., Hoekstra J.A., Concentrate supplementation of grazing dairy cows. 1. Effect of 
concentrate intake and herbage allowance on herbage intake, Grass For. Sci. 39 (1984) 59-66.

[28] Peyraud J.L., Comeron E.A., Wade M., Lemaire G., The effect of daily herbage allowance, herbage mass and animal factors upon herbage intake by grazing dairy cows, Ann. Zootech. 45 (1996) 201-217.

[29] Politis I., Ng-Kwai-Hang K.F., Effects of somatic cell count and milk composition on the coagulation properties of milk, J. Dairy Sci. 71 (1988) 1740-1746.
[30] Wales W.J., Doyle P.T., Dellow D.W., Dry matter intake and nutrient selection by lactating cows grazing irrigated pastures at different pasture allowance in summer and autumn, Aust. J. Exp. Agric. 38 (1998) 451-460.

[31] Zemp M., Leuenberger H., Künzi N., Blum W., Influence of high altitude grazing on productive and physiological traits of Dairy cows. I: Influence on milk production and body weight, $\mathrm{J}$. Anim. Breed. Genet. 106 (1989) 278-288. 